\title{
Some morphological and physiological characteristics of South Karaman Sheep: I- Morphological features, body measurements and live weights
}

\author{
Dilek Tüney Bebek ${ }^{1}(0)$, Mahmut Keskin $^{2 *}($ ) \\ ${ }^{1}$ Mustafa Kemal University, Graduate School of Natural and Applied Sciences Antakya, Hatay, Turkey. \\ ${ }^{2}$ Mustafa Kemal University, Department of Animal Science, Faculty of Agriculture Antakya, Hatay, Turkey.
}

\section{Article History}

Received: 01 April 2020

Accepted: 05 October 2020

First Online: 12 October 2020

\section{Corresponding Author}

Tel.: 0 (326) 245 5845-1336

E-mail:mkeskin@mku.edu.tr

\section{Keywords}

Colour

Horn

Tail type

Body measurement

Live weight

\begin{abstract}
In this study, it was aimed to determine the morphological features, body measurements and weights of South Karaman sheep, which is preferred especially by nomadic breeders in Mersin. The animal material of the study consisted of 100 head South Karaman sheep raised in the nomadic system in Tarsus district of Mersin province. The sheep which remained in the tent in the Bahşiş village that is neighbour of the Tarsus district of Mersin province in winter period, and then they migrated to the Çilnili Lake, which is located within the borders of Çamlıyayla district of Mersin province from the beginning of June to the end of October. In the study, morphological features were determined by observation, and body measurements and weights were determined by measuring. At the end of the study, it was determined that the South Karaman sheep are generally black or blackish ash colour. Males of this breed are usually horned and females are hornless. It was also determined that there is an " $\mathrm{S}$ " shaped structure at the end of the fat tail in South Karaman sheep.
\end{abstract}

\section{Introduction}

Turkey with the high size of sheep, goats and the cattle population is among the leading countries in the world. However, it can be said that sheep population of Turkey decreased by $16.7 \%$ in the last quarter century although it has increased in recent years (Hayvansal Üretim, 2018). This decrease is mainly due to the incentives or supports applied to dairy cattle breeding, reducing in pasture areas and terrorism problems. The fact that sheep breeders prefer to be intensive cattle raising has increased milk production in Turkey and caused serious problems in meat production. At this point, since the climate and pasture characteristics are not suitable for dairy cattle in most of the country the increasing feed prices cannot cover the cost of milk. It is known that Turkey's pastures that usually has poor quality are suitable for sheep rather than cattle. In sheep breeding, there are both breeds with high genetic potential suitable for intensive production and domestic breeds with low yield capacity suitable for traditional production.

Although not involved in the Turkish Statistical Institute data, we know that the different breeds are raised in different regions of Turkey. For example, White Karaman, Red Karaman, South Karaman, Sakız, Awassi, Hamdani, Herik and Merino sheep are bred in Mersin. In the region where nomadic sheep breeding is still widespread, the nomadic breeders prefer the South Karaman sheep (named as Güney Karaman in Turkish) mostly because it is resistant to natural conditions (Bebek and Keskin, 2018).

There is not much information about South Karaman sheep in the literature. However, it can be said that the South Karaman sheep is a breed that is under threat of extinction in terms of pure breeding. Although it is 
evaluated this breed is located in the Mediterranean region covering the provinces of Antalya, Mersin, Adana, Gaziantep and Hatay (Özcan, 1989), it is estimated to be the most common in and around Mersin. These sheep, which are accepted as a variant of Karaman sheep (Özcan, 1989) are generally raised in a nomadic system. It is mostly raised as herds by nomads named as Yörük. Although it has been pointed out in various sources that it exists in our country, it is seen that there are not sufficient and detailed studies on the morphological and physiological characteristics of the South Karaman sheep. In this study, it was aimed to determine the morphological features, body measurements and weights of South Karaman sheep.

\section{Materials and Methods}

The animal material of the study consisted of 100 head female and 10 head male South Karaman sheep raised in the nomadic system in Tarsus district of Mersin province. The flock was managed under breeders' condition. The herd remained in a tent in the district of Tarsus, of Mersin province $\left(36^{\circ} 46^{\prime}\right.$ North and $34^{\circ} 54^{\prime}$ East) from 01 November 2017 until 30 May 2018. After this date, they migrated to the Çinili Lake $\left(37^{\circ} 38^{\prime}\right.$ North and $34^{\circ} 51^{\prime}$ East) located in the borders of Çamliyayla district of Mersin, with an altitude of approximately 2500 m. They returned to Tarsus again on October 20, 2018.

In addition to the pasture, $60 \mathrm{~kg}$ of straw and 50 $\mathrm{kg}$ of concentrate feed were given to the animals during their stay in Tarsus (40 heads primiparous, 52 heads multiparous, 4 heads infertile and 4 heads aborted). The feeding of animals was provided only by grazing in the pasture during the highland period.

One ram was used for 10 head female animals in mating period. The rams were constantly kept in the herd and the dates they mated were recorded. If a sheep did not show oestrus after mating, it was accepted that she became pregnant. The births started from November 2017 and continued until April 22, 2018.

Body length, withers height, rump height, front chest width, front chest depth and chest circumference were determined as specified by Boztepe et al. (1997). All ewes were weighed both on the last 30-45 days of pregnancy and the day after birth. Fleece colour, ear structure, horn condition, horn structure and tail structure were determined by evaluating the animals one by one.

The mathematical model for body weight and sizes is as follows;

$$
\begin{aligned}
& Y_{i j}=\mu+\alpha_{i}+e_{i j} \\
& Y_{i j} \text {, recorded value of the ewes in the } i^{\text {th }} \text { age group }
\end{aligned}
$$

$\mu$, mean of the population

$\alpha_{i}$, effect of age groups

$\mathrm{e}_{\mathrm{ij}}$, error term

Statistical analysis of the study was evaluated with SPSS package program (SPSS Statistic 17.0.Ink).

\section{Results and Discussion}

\section{Morphological Characteristics}

Morphological features are features related to colour, shape, size of size and type, which can be seen immediately when viewed from the outside. Each breed has its own colour and even pattern. In this study, it was determined that South Karaman sheep are usually black or blackish ash colour (69\%), but also dark brown and pied individuals can be found (Figure 1, 2, 3 and 4). It has been reported by various researchers that South Karaman sheep is generally black in color, and it is seen in brown, ash, white and pied colours (Özcan, 1989; Öztürk, 2000). Özcan (1989) reported that black colour turned into ash colour with the advancement of age in South Karaman sheep as in Karakul sheep. In the present study, it was determined that the South Karaman sheep have medium length and drooping ears and the males are horned. The spiral shaped and curved forward horn can be seen in Figure 1 and the short and thin horn can be seen in Figure 2 in the rams.

It is observed that the females are generally hornless in the South Karaman sheep (Figure 3). In the study, the rate of horned females was determined as $3 \%$. Özcan (1989) reported that male horned females rarely horned in South Karaman sheep. In Karagül sheep, which are considered to be related with South Karaman sheep, male individuals are horned and female individuals are hornless (Uğur, 2006).

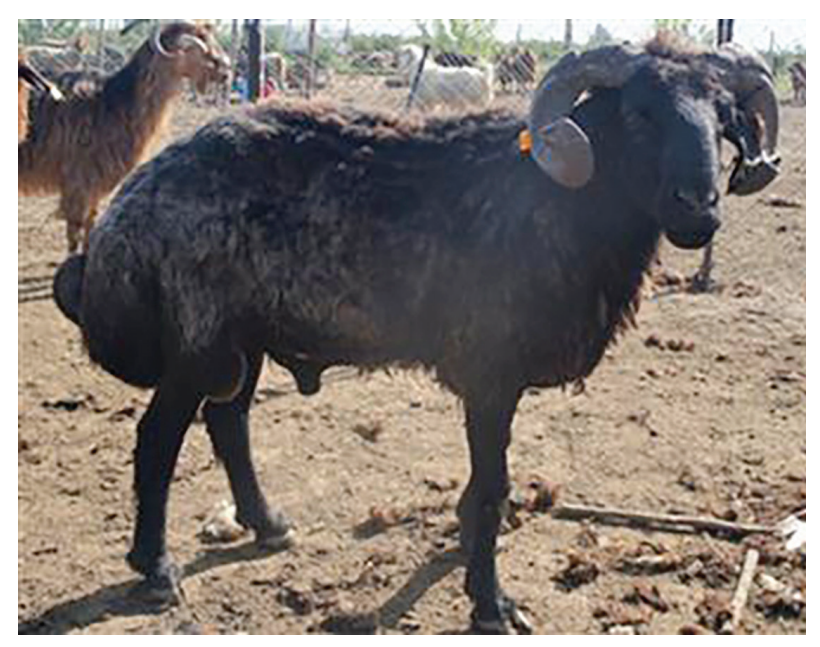

Figure 1. South Karaman ram with spiral horns. 


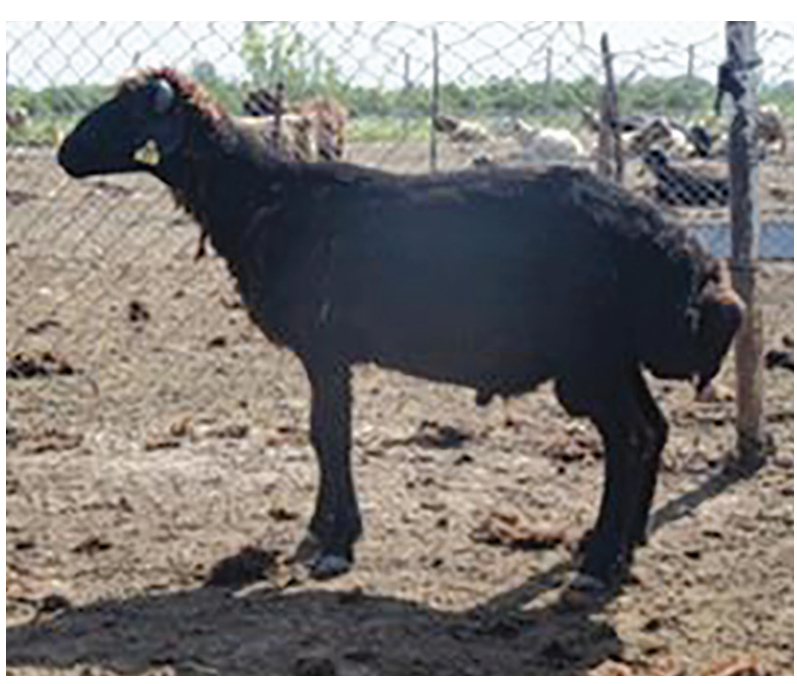

Figure 2. South Karaman ram with short and thin horns.

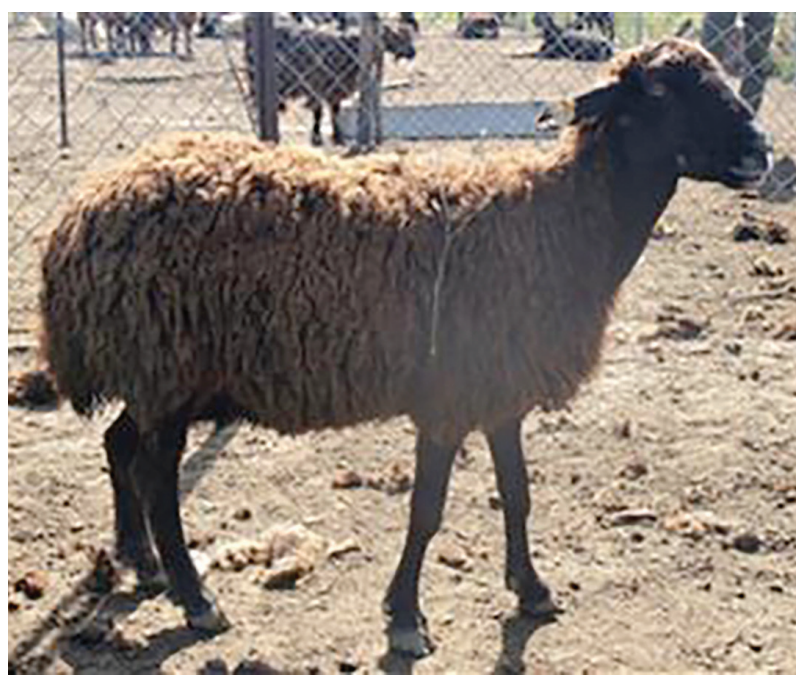

Figure 3. South Karaman female sheep.

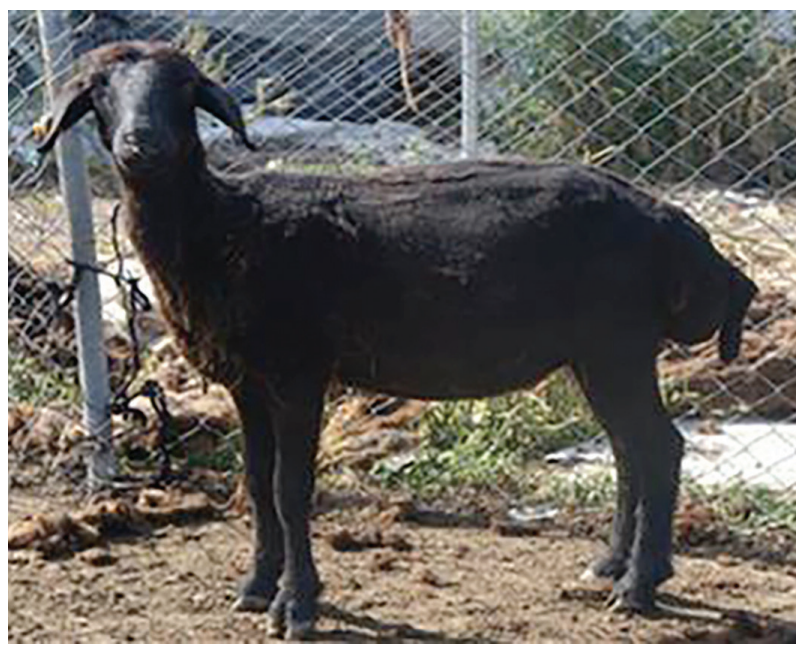

Figure 4. View of the tail structure in the sheared South Karaman sheep.
In the study, it was determined that there is an Sshaped structure at the end of the tails of the sheep. The "S" shaped structure at the tip of the tail in the South Karaman sheep with fat tail is one of the distinctive features of this breed (Figure 4).

In the paper on the Registration of Domestic Animal Breeds and Lines published by the Ministry of Agriculture and Forestry, it is stated that the South Karaman sheep are fatty tailed and the tip of the tail hangs down in the form of fingers or " $\mathrm{S}$ " (Yerli Hayvan Irk ve Hatlarının Tescili Hakkında Tebliğ, 2004; Küçükbaş Hayvan Seçimi, 2013; Cografya Dünyası, 2014). As stated also by Hunter (2015), the tail end in an " $\mathrm{S}$ " shaped formation in Karagül (Karakul) sheep.

South Karaman is the most preferred breed by nomadic breeders in Mersin region because it is suitable for nomadic animal husbandry (Bebek and Keskin, 2018). Because they are resistant to difficult conditions, nomadic breeders prefer to breed South Karaman as pure as possible. The fact that South Karaman sheep is preferred in sheep breeding with nomadic system in Mersin region by different researchers (Aydın and Keskin, 2018; Bebek and Keskin, 2018; Karagöl and Keskin, 2018) indicate that the system is sustainable with native breeds despite various difficulties. The migration of South Karaman sheep from the sea level to the high plateaus and continuing its life in conditions that can be called extensively in areas with very different altitudes causes this breed to be preferred by the breeders. Other reasons why nomadic breeders prefer this breed are the fact that they give a lamb per year (breeder do not want many births because of low milk yield of dams), they are resistant to diseases, and have long walking ability due to nail structure. Özcan (1989) stated that the South Karaman sheep, which has high tolerance to heat and cold, has been grazing up to $2000-2500 \mathrm{~m}$ altitude in spring and returned to the seaside in autumn. Ertuğrul et al. (2005) reported that South Karaman sheep, like all domestic breeds, are very well adapted to insufficient environmental conditions as they are bred in the region for many years. This breed is both durable and that they can birth even under insufficient environmental conditions. Karakul sheep, considered to be related to Southern Karaman sheep, are also extremely resistant to harsh conditions and can live in desert conditions and consume saltwater (Hunter, 2015).

\section{Body Measurements and Live Weights}

Body measurements and live weights are important features that can be used to differentiate breeds and are therefore used in breed definitions. From these measures, especially live weight can change before and after birth (Table 1). Also, since the animal can continue to de- 
velop after giving birth for the first time, the age of the animal may also have an effect on body measurements and weights (Table 2).

Table 1. Variation of live weights with birth type in South Karaman sheep $(\bar{x} \pm$ se)

\begin{tabular}{lcccc}
\hline Traits & Single (60) & Twin (32) & $\mathbf{P}$ & Total \\
\hline Live weight $^{1}$ & $50.6 \pm 0.87$ & $58.9 \pm 0.99$ & $<0.01$ & $53.2 \pm 0.77$ \\
Live weight $^{2}$ & $44.6 \pm 0.86$ & $49.3 \pm 0.94$ & $<0.05$ & $46.1 \pm 0.69$ \\
\hline
\end{tabular}

Live weight ${ }^{1}$, live weight in the last $30-45$ th days of gestation; Live weight $^{2}$, live weight after birth; $\bar{x}$, mean; se, standard error

As can be seen from Table 1, the average body weight of ewes taken after birth was $50.6 \pm 0.87$ and $58.9 \pm 0.99 \mathrm{~kg}$ in the single and twin births, respectively $(P<0.01)$. It was determined that the mean body weight difference, which was $8.3 \mathrm{~kg}$ between the single and twin births, decreased to $4.7 \mathrm{~kg}$ by decreasing in weighting made after birth, and the live weights for both groups were $44.6 \pm 0.86$ and $49.3 \pm 0.69$, respectively. It is normal for the sheep that give twin birth have higher prenatal body weight than those who give single birth when maintenance and feeding are sufficient (Demirel et al., 2000). Effect of the age of the experimental ewes on their body weight and body measurements are seen in Table 2. These findings show that the growth and development for South Karaman ewes continues after the age of 2. These values determined in the experimental South Karaman sheep are similar to the values reported by different researchers (Ayhan, 2015; Yılmaz et al., 2013). Thus, Ayhan (2015) reported wither height, body length, and adult body weight as $63 \mathrm{~cm}, 58 \mathrm{~cm}$ and 37 $\mathrm{kg}$, respectively for South Karaman sheep. Same way, Yilmaz et al. (2013) informed these values for same characters as $63 \mathrm{~cm}, 58 \mathrm{~cm}$ and $47 \mathrm{~kg}$, respectively. Akay et al. (2018) reported chest circumference, height of wither, height of rump, body length, width of front chest and width of rump in South Karaman ewes as $84.49 \mathrm{~cm}$, $62.95 \mathrm{~cm}, 62.72 \mathrm{~cm}, 61.55 \mathrm{~cm}, 17.51 \mathrm{~cm}$ and $18.87 \mathrm{~cm}$, respectively. It is seen that the values determined in the current study are compatible with the body size values reported by Akay et al. (2018). The differences between the values of body measurements determined in the present study and those reported for Karakul sheep by Erol and Akçadağ (2009) may have caused from the differences in breeding conditions and breeds.

Table 2. Change of body weight and body size in experimental sheep according to age ( $\bar{x} \pm$ se)

\begin{tabular}{lcccc}
\hline Traits & $\mathbf{1 8 - 2 4}$ months $(\mathbf{n = 4 0 )}$ & $\mathbf{3 6}$ months and up $(\mathbf{n = 5 2 )}$ & $\mathbf{P}$ & Total \\
\hline Body weight $^{1}$ & $47.5 \pm 1.06$ & $57.1 \pm 0.75$ & $<0.01$ & $53.2 \pm 0.77$ \\
Body weight $^{2}$ & $41.0 \pm 0.90$ & $49.3 \pm 0.70$ & $<0.01$ & $46.1 \pm 0.69$ \\
Wither height & $63.0 \pm 0.33$ & $64.5 \pm 0.27$ & $<0.01$ & $63.9 \pm 0.22$ \\
Rump height & $64.9 \pm 0.36$ & $66.4 \pm 0.28$ & $<0.01$ & $65.8 \pm 0.23$ \\
Body length & $58.7 \pm 0.67$ & $61.5 \pm 0.46$ & $<0.01$ & $60.4 \pm 0.41$ \\
width of front chest & $19.6 \pm 0.24$ & $20.7 \pm 0.20$ & $<0.01$ & $20.3 \pm 0.20$ \\
Chest circumference & $99.1 \pm 1.11$ & $106.7 \pm 0.79$ & $<0.01$ & $103.6 \pm 0.75$ \\
\hline
\end{tabular}

Live weight ${ }^{1}$, live weight in the last $30-45$ th days of gestation; Live weight ${ }^{2}$, live weight after birth; $\bar{x}$, mean; se, standard error

\section{Relationships Between Body Weight and Body Measurements}

The relationship between live weight and different body measurements, especially chest circumference, in sheep and goats is expressed by different researchers (Gül et al,, 2005; Koç and Akman, 2007; Şahin et al., 2018). These relations allow to using of the size of the chest circumference, which is more practical than weighting the animal, in market conditions where the animal trade is based on live weight.

The correlation coefficients and the statistical significance levels between the different body measurements and live weight values determined from the experimental sheep are given in Table 3. Although there were significant $(P<0.01)$ correlations between the features mentioned in Table 3 , regression equations have been created for the relationship between chest circumference and body weight, which have the highest correlation coefficient and practical usage.

Accordingly, the regression equations between body weight and chest circumference for gestational period and after birth period were formulated as "Live weight $=-23.5+0.74 \times$ Chest circumference" and "Live weight $=-17.1+0.61 \times$ Chest circumference", respectively.

The correlation coefficient between these two properties for same periods were calculated as 0.711 and 0.658 , respectively $(P<0.01)$. Live weights estimated by the calculated regression equation were given in Table 4. 
Table 3. Correlation coefficients between different body sizes and weights

\begin{tabular}{lccccccc}
\hline & LW $^{1}$ & LW $^{2}$ & WH & RH & BL & FCW & CC \\
\hline LW $^{1}$ & 1 & $0.964^{* *}$ & $0.343^{* *}$ & $0.415^{* *}$ & $0.354^{* *}$ & $0.577^{* *}$ & $0.711^{* *}$ \\
LW $^{2}$ & & 1 & $0.312^{* *}$ & $0.357^{* *}$ & $0.343^{* *}$ & $0.539 * *$ & $0.658^{* *}$ \\
WH & & & 1 & $0.791^{* *}$ & $0.504^{* *}$ & $0.321^{* *}$ & $0.376^{* *}$ \\
RH & & & & 1 & $0.537^{* *}$ & $0.387^{* *}$ & $0.440^{* *}$ \\
BL & & & & & 1 & $0.289^{* *}$ & $0.360^{* *}$ \\
FCW & & & & & & 1 & $0.654^{* *}$ \\
CC & & & & & & & 1 \\
\hline
\end{tabular}

$\mathrm{LW}^{1}$, live weight in the last 30-45th days of gestation; LW2, live weight after birth; WH, Wither height; RH, Rump height; $\mathrm{BL}$, Body length; FCW, width of front chest; $\mathrm{CC}$, chest circumference; ${ }^{* *}, \mathrm{P}<0.01$

Table 4. The relationship between live weight during pregnancy and chest circumference

\begin{tabular}{|c|c|c|c|c|c|c|c|c|c|c|}
\hline \multicolumn{11}{|c|}{ Last 30-45th days of gestation } \\
\hline $\mathrm{CC}$ & 90 & 92 & 94 & 96 & 98 & 100 & 102 & 104 & 106 & 108 \\
\hline LW & 43.1 & 44.6 & 46.1 & 47.5 & 49.0 & 50.5 & 52.0 & 53.5 & 54.9 & 56.4 \\
\hline \multicolumn{11}{|c|}{ After Birth } \\
\hline $\mathrm{GÇ}$ & 90 & 92 & 94 & 96 & 98 & 100 & 102 & 104 & 106 & 108 \\
\hline CA & 37.8 & 39.2 & 40.2 & 41.5 & 42.7 & 43.9 & 45.1 & 46.3 & 47.6 & 48.8 \\
\hline
\end{tabular}

CC, chest circumference, LW, Live weight

This type of correlation and regression study has not been found in the literature in South Karaman ewes. However, they were reported correlations between live weight and body measurements ranging from 0.674 to $0.788(P<0.01)$, and expressed the regression equation between live weight and chest circumference as "live weight $=-51.8+1.04$ chest circumference" for Anatolian Merino ewes by Şahin et al. (2018).

\section{Conclusions}

The production purpose in sheep breeding can vary according to the countries. As concepts such as global climate change and organic production, became widespread in Turkey the importance of native breeds raised for both milk and meat is better understood. In addition, considering the suitability of nomadic breeding, South Karaman sheep is an important local gene source. In this study, the followings have been stated as conclusions; (a) this breed has generally black or blackish ash and dark brown colours, males were horned and females were hornless, has a fatty tail with an " $\mathrm{S}$ " shaped extension at the end, (b) there were statistically significant correlations between different body measurements and body weight scales and the highest correlation coefficient was determined between body weight and chest circumference, (c) Live weight can be estimated safely by measuring the chest circumference in the establishment where it is not possible to weigh the sheep.

\section{Acknowledgements}

This manuscript has been prepared as part of a PhD thesis entitled as "Some Morphological and Physiological Features of South Karaman Sheep". The authors thank Coordinatorship of Scientific Research Projects of Hatay Mustafa Kemal University (Project No: 17.D.002) which provides financial support to the study.

\section{References}

Akay, N., Yılmaz, T. C. \& Yılmaz, O. (2018, May 09-12). Live weight estimation based on linear body measurements of South Karaman sheep breed, [Paper presentation], I. International Agricultural Science Congress, Van/Turkey.

Yerli Hayvan Irk ve Hatlarının Tescili Hakkında Tebliğ. (2004). https://www.mevzuat.gov.tr/mevzuat?MevzuatNo=6109\& MevzuatTur=9\&MevzuatTertip=5 Tebliğ no:2004/39. Resmi Gazete Tarihi: 12.12.2004, sayısı: 25668.

Küçükbaş Hayvan Seçimi. (2013). T.C. Milli Eğitim Bakanlığı, Hayvan Yetiştiriciliği, Küçükbaş Hayvan Seçimi. http://docplayer. biz.tr/12421685-Hayvan-yetistiriciligi.html

Cografya Dünyası. (2014). Mersin Ekonomik Faaliyetler, http:// www.cografya.gen.tr/tr/mersin/ ekonomi.html

Hayvansal Üretim. (2018). http://www.tuik.gov.tr/UstMenu. do?metod=temelist

Aydın, M. K. \&, Keskin, M. (2018). Muğla ilinde küçükbaş hayvan yetiştiriciliğinin yapısal özellikleri. Mediterranean Agricultural Sciences, 31: 317-323.

Ayhan, V. (2015). Koyun Keçi Irklarımız Tanıtım Kılavuzu. Türkiye Damızlık Koyun Keçi Yetiştiricileri Merkez Birliği, Yayın No: 5, Ankara.

Bebek, D. T. \& Keskin, M. (2018). Mersin ilinde koyun yetiştiriciliğinin mevcut durumu bazı verim ve yapısal özellikleri. Mustafa Kemal Üniversitesi Ziraat Fakültesi Dergisi, 23(2): 315-323.

Boztepe, S., Dağ, B., Parlat, S. S., Yıldız, A. Ö. \& Aktaş, A. H. (1997). Yağlı kuyruklu kimi yerli ırk kuzuların besi performansı ve karkas özellikleri. Selçuk Üniversitesi Araştırma Fonu. Proje No: ZF-95/064. Konya

Demirel, M., Aygün, T., Altnn, T. \& Bingöl, M. (2000). Hamdani ve Karakaş koyunlarında gebeliğin son döneminde farklı düzeylerde beslemenin koyunlarda canlı ağırlık, kuzularda doğum 
ağırlığı ve büyüme üzerine etkileri. Turkish Journal of Veterinary and Animal Sciences, 24: 243-249.

Erol, H. \& Akçadağ, H. í. (2009). Halk elinde yetiştirilen Karagül koyun sürülerinde bazı verim özellikleri. Lalahan Hayvancılık Araştırma Enstitüsü Dergisi, 49(2): 91-104.

Ertuğrul, M., Dellal, G., Elmacı, C., Akın, O., Karaca, O., Altın, T. \& Cemal, i. (2005). Hayvansal gen kaynaklarının koruma ve kullanımı. https://www.zmo.org.tr/resimler/ ekler/92cb13c22d51c22_ek.pdf?tipi=14\&sube=

Gül, S., Görgülü, O., Keskin, M., Biçer, O. \& Sarı, A. (2005). Some prediction equations of live weight from different body measurements in Shami (Damascus) goats. Journal of Animal and Veterinary Advances, 4(5) : 497-501.

Hunter, D. Y. (2015). Karakul sheep. The Livestock Conservancy News. Spring. 2015, page 6-9. https://karakulsheep.files.wordpress.com/2016/01/karakul-sheep-lc-news-spring-2015.pdf.

Karagöl, E. \& Keskin, M. (2018). Problems of nomadic goat breeders and their effects on forest. Mugla Journal of Science and Technology, 4(1): 11-15.
Koç, A. \& Akman, N. (2007). Siyah-Alaca tosunların değişik dönemlerdeki vücut ölçüleri ve vücut ölçülerinden canlı ağırlığın tahmini. ADÜ Ziraat Fakültesi Dergisi, 4(1-2): 21 - 25.

Özcan, L. (1989). Küçükbaş Hayvan Yetiştirme-II. Çukurova Üniversitesi Ziraat Fakültesi Yayınları No: 108, Adana.

Öztürk, A. (2000). Koyunculuk ve Yapağı. Selçuk Üniversitesi Zootekni Bölümü Ders notları. Konya.

Şahin, Ö., Boztepe, S. \& Keskin, İ. (2018). Anadolu Merinosu erkek kuzularında besi dönemi vücut ölçülerine ait ortalamalardan canlı ağırlık, canlı ağırlık artı̧ı ve yem tüketiminin tahmini. Selcuk Journal of Agriculture and Food Sciences, 32(2); 142-145.

Uğur, F. (2006). Genel Hayvan Yetiştirme, Ders Notu. Çanakkale Onsekiz Mart Üniversitesi Ziraat Fakültesi Zootekni Bölümü.

Yılmaz, O., Cengiz, F., Ertuğrul, M. \& Wilson, R. T. (2013). The domestic livestock resources of Turkey: Sheep breeds and crossbreeds and their conservation status. Animal Genetic Resources, 52: 147-163. 